\title{
LOW-COST MICROPROCESSED INSTRUMENT FOR EVALUATING SOIL TEMPERATURE PROFILE ${ }^{1}$
}

\author{
PAULO ESTEVÃO CRUVINEL²
}

\begin{abstract}
This paper describes a low-cost microprocessed instrument for in situ evaluating soil temperature profile ranging from $-20.0^{\circ} \mathrm{C}$ to $99.9^{\circ} \mathrm{C}$, and recording soil temperature data at eight depths from 2 to $128 \mathrm{~cm}$. Of great importance in agriculture, soil temperature affects plant growth directly, and nutrient uptake as well as indirectly in soil water and gas flow, soil structure and nutrient availability. The developed instrument has potential applications in the soil science, when temperature monitoring is required. Results show that the instrument with its individual sensors guarantees $\pm 0.25^{\circ} \mathrm{C}$ accuracy and $0.1^{\circ} \mathrm{C}$ resolution, making possible localized management changes within decision support systems. The instrument, based on complementary metal oxide semiconductor devices as well as thermocouples, operates in either automatic or non-automatic mode.
\end{abstract}

Index terms: soil management equipment, thermal properties, microprocessors, sensors.

\section{INSTRUMENTO MICROPROCESSADO DE BAIXO CUSTO PARA AVALIAÇÃO DA TEMPERATURA EM PERFIL DE SOLO}

\begin{abstract}
RESUMO - Este artigo descreve um instrumento microprocessado de baixo custo para avaliação in situ da temperatura em perfil de solo na faixa de $-20,0^{\circ} \mathrm{C}$ a $99,9^{\circ} \mathrm{C}$ com armazenagem de dados de até oito profundidades, de 2 a 128 centímetros. A temperatura do solo é de grande importância para o crescimento de plantas, absorção de nutrientes, fluxo de gases e estrutura. O instrumento desenvolvido encontra várias aplicações na área da ciência do solo, onde o monitoramento de temperatura do solo é requerido. Resultados mostram que a caracterização do instrumento e seus sensores individuais garantem uma acurácia de $\pm 0,25^{\circ} \mathrm{C}$ e uma resolução de $1,0^{\circ} \mathrm{C}$. Também proporciona a produtores ou pesquisadores a oportunidade do manejo localizado para sistemas de tomada de decisão. O instrumento é baseado em dispositivos semicondutores com tecnologia de óxido metálico complementar e termopares. E pode operar tanto no modo manual quanto no modo automático.
\end{abstract}

Termos para indexação: equipamento para manejo do solo, propriedades térmicas, microprocessador, sensores.

\section{INTRODUCTION}

Until recently, the use of electronics technology for soil science involving measurement and control systems design has been limited to research. For many years, the most sophisticated apparatus used was an on-off or a proportional thermostat with a liquid-filled bulb. In many instances, particularly in mild climates,

\footnotetext{
${ }^{1}$ Accepted for publication on July 19, 2000.

${ }^{2}$ Engineer, Ph.D, Embrapa-Centro Nacional de Pesquisa e Desenvolvimento de Instrumentação Agropecuária (CNPDIA), Caixa Postal 741, CEP 13560-970 São Carlos, SP, Brazil. E-mail: cruvinel@cnpdia.embrapa.br
}

regulating plant and animal environments required manually adjusting curtains, tilt-out panels, dampers, and spray nozzles. Although integrated circuits (IC's) have been available since the early 60's, only in recent years have these powerful building blocks been used in designing analog devices such as amplifiers and filters, as well as digital logic circuits for instrumentation, data logger, and measurement systems. Intel Corporation introduced the first microprocessor, the Intel 4004 (Gupta \& Toong, 1983) only 27 years ago. Its successors gave birth to today's growing personal computer industry and the resulting computer revolution. The subsequent prices drop of microprocessor-based instrumentation measure and control components made widely available to 
engineers a versatile tool for systems design. By using microprocessors as central parts of a system, the engineer can now simplify the task. First, one can interfaces to the microprocessor all inputs, both digital and analog, by means of an analog to digital converter, and connects outputs using appropriate circuitry such as buffers, digital to analog converters, amplifiers and so on. That done, by changing the software, one can read inputs and control outputs as desired. While personal computers have high public visibility and extensive press coverage, a far greater number of microprocessors are increasingly found in industrial controllers, consumer products, research instruments, and agricultural instrumentation for in situ use.

Of great importance in agriculture, soil temperature affects plant growth directly, e.g., in seed germination, root growth and nutrient uptake as well as indirectly in soil water and gas flow, soil structure and nutrient availability. Its influence on plants development and seed germination has been reported in the literature (Coffman, 1923; Gist \& Mott, 1957; Dubetz et al., 1962; Allmaras et al., 1964; Smith, 1968).

In a further step, the Fourier analysis, reported as describing temperature variation in soil with time (Wijk, 1963; Nerpin \& Chudnovskii, 1970), assumes boundaries and isotropic soils as well as a linear relationship between air and soil temperatures at a $2.54 \mathrm{~cm}$ depth. Even though mathematical models exist for predicting soil temperature and moisture variations using both soil properties and climatological data, no simple prescriptions exist for convergence (Rosena, 1975; Hasfurther \& Burman, 1979; Wierenga et al., 1982; Schieldge et al., 1982; Vieira et al, 1983; Blackmore, 1999), therefore, in situ measurements are still quite useful and often required.

This paper describes a low-cost microprocessed instrument for in situ evaluating soil temperature profiles, and also discusses the metrological, methodological and technological fundamentals of the proposed approach. The developed instrument has potential applications in the soil science, when temperature monitoring is required. Its use extends to irrigation operations, where management is often triggered by factors such as soil water content.

\section{MATERIAL AND METHODS}

\section{System description}

Fig. 1 shows the system configuration in a block diagram. The hardware is comprised of: a shaft (white-polyethylene pipe) $180 \mathrm{~cm}$ long and $2 \mathrm{~cm}$ in diameter and a set of eight stainless-steal needles $9.7 \mathrm{~cm}$ long and $0.3 \mathrm{~cm}$ external diameter for sensor installation; a set of eight thermocouples (cooper-constantan) with a temperature coefficient of $25 \mu \mathrm{V} /{ }^{\circ} \mathrm{C}$ (Embrapa, 1989); an electronic system for cold junction compensation; an input amplifier; an A/D converter, a 3-1/2 digit LED display; an analog multiplexer; an electronic system for mode selection; and interface with a dedicated microprocessor architecture with two $3 \frac{1}{2}$ " floppy disk units. This architecture, based on a Motorola 6502 microprocessor, makes it possible to connect a video display as well as a printer to access a chosen data file, or even to transmit to a host computer by means of a serial interface soil-temperature profile data.

Using extension grade thermocouple wire the shaft with sensors is mobile within $100 \mathrm{~m}$. Thermocouples were assembled inside of needles to minimize soil disturbance effects during sensor installation. To obtain soil temperatures at depths of 2, 4, 6, 8, 16, 32, 64 and $128 \mathrm{~cm}$ the needles with the thermocouples were distributed on the shaft, according to profile requirements. A commercially available LM725A was used to assemble the input amplifier due to its performance in applications requiring low noise, low drift and accurate closed-loop gain. A commercially available Intersil ICL 7107 integrated circuit was used to convert analog signals from thermocouples to digital signals for the interface. After linearization and averaging, data appear on a 3-1/2 LED display. The interface circuit was designed using two Motorola 6821 peripheral interface adapter integrated circuits. These I/O ports are used to interface with the dedicated microprocessor architecture the A/D converter, analog multiplexer, as well as external timer. Fig. 2 shows interface schematic diagram together with the mode selector operation circuit and the corresponding time sequence.

Operating in automatic mode, the instrument employs an algorithm developed using both Pascal and Assembly language. Fig. 3 shows as a flow chart the algorithm for microprocessed automated control operation. The main experiment control loop is entered following initialization of a data temperature file, using selection of initial parameters for temperature measurement. Control software allows selecting initial milivoltmeter scale setting, and programming of acquisition time interval for sensor scanning, data acquisition, average filtering, data linearization and data storage on floppy disk. Files will hold up to 64 kbytes 
and data are stored in ASCII format. However, in nonautomatic mode only the routines for average filtering, data linearization and read-out on a 3-1/2 LED display are used for a pre-selected sensor.

The low-cost microprocessed instrument for in situ evaluating soil temperature profile was developed at the Embrapa-Centro Nacional de Pesquisa e Desenvolvimento de Instrumentação Agropecuária, São Carlos, SP, Brazil.

\section{System evaluation}

A set of soil temperature measurements was made in order to evaluate instrument performance under field conditions. Each sensor was calibrated against an accurate thermometer with $\pm 0.1 \%$ error in the $-20.0^{\circ} \mathrm{C}$ to $100.0^{\circ} \mathrm{C}$ range. Conventional true temperature value was obtained using a reference-grade platinum RTD sensor. Thus, instrument can provide measurements with less than $\pm 1.5 \%$ error; a typical calibration curve for one of the sensors appears in Fig. 4.

To minimize noise during operation, each sensor was scanned eight times with filtering done by arithmetic averaging. The instrument was shielded to avoid stray leak- age and humidity effects within ambient temperatures up to $65^{\circ} \mathrm{C}$ and relative humidity up to $85 \%$ (non-condensing).

The instrument was configured in automatic mode to simultaneously perform operations required for temperature data collection for soil profile. For the first and foremost task, measurements of the components of the temperature vector to the microprocessed system were housed in a weatherized small plastic box with environmental enclosure. The second task requires retrieving soil temperature profile data every 30 minutes and appending it to an existing file.

To avoid the constraints of using standard line power, the entire system is designed to operate on 12 volts DC, making it completely portable. The instrument including the entire soil temperature profile sensors system is powered by nine deep-cycle 12 VDC batteries charged daily by solar panels (M75, Siemans, Inc.). The regulator is equipped with a low-voltage option that disconnects electronic devices with greater power consumption when the battery voltage falls below 11.5 VDC.

Soil temperature data for instrument evaluation under field conditions were stored during 60 days with a 1-hour pre-selected acquisition-time interval. Both grass-covered and bare soils were studied.

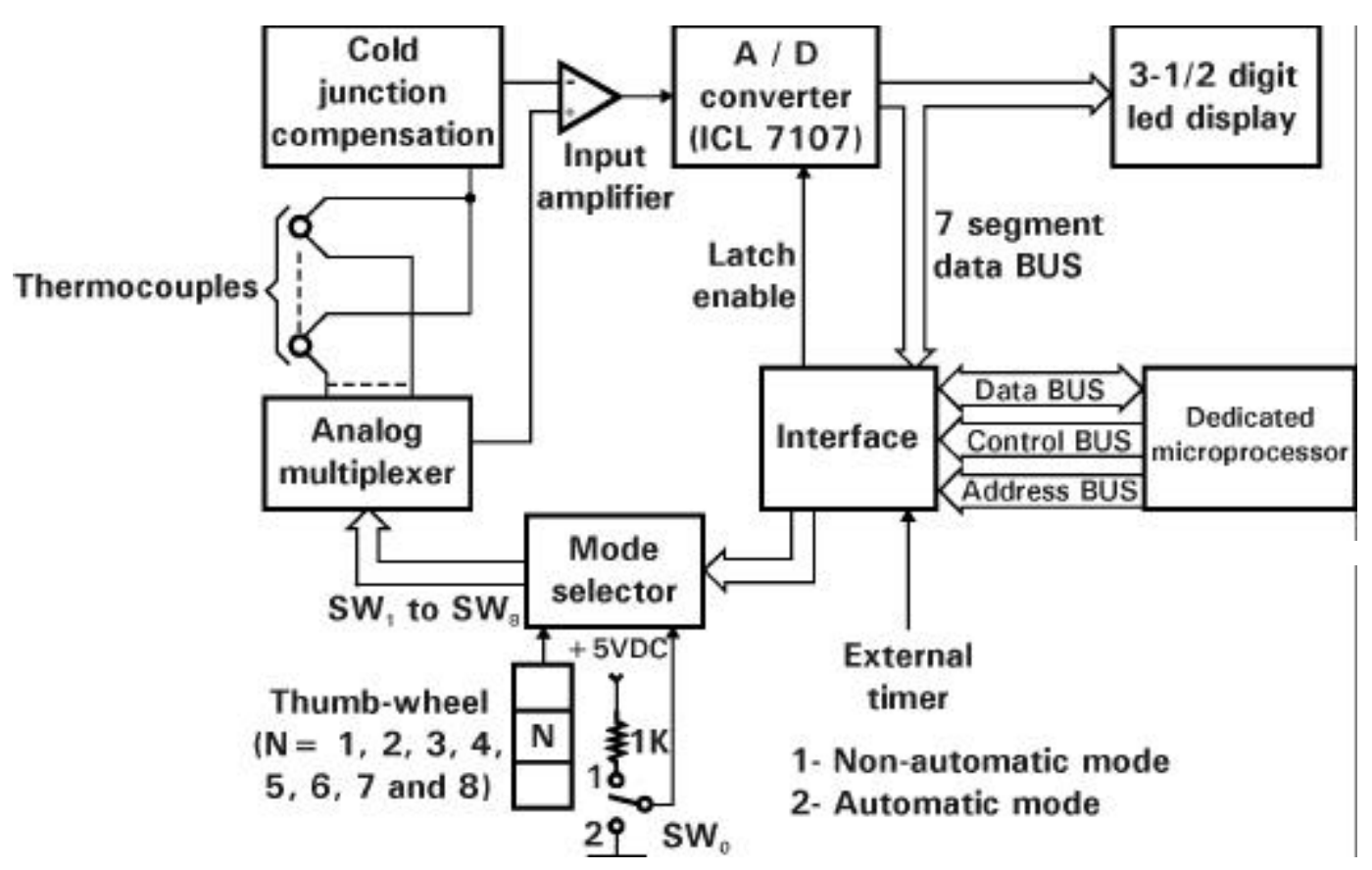

FIG. 1. System configuration in block diagram. 


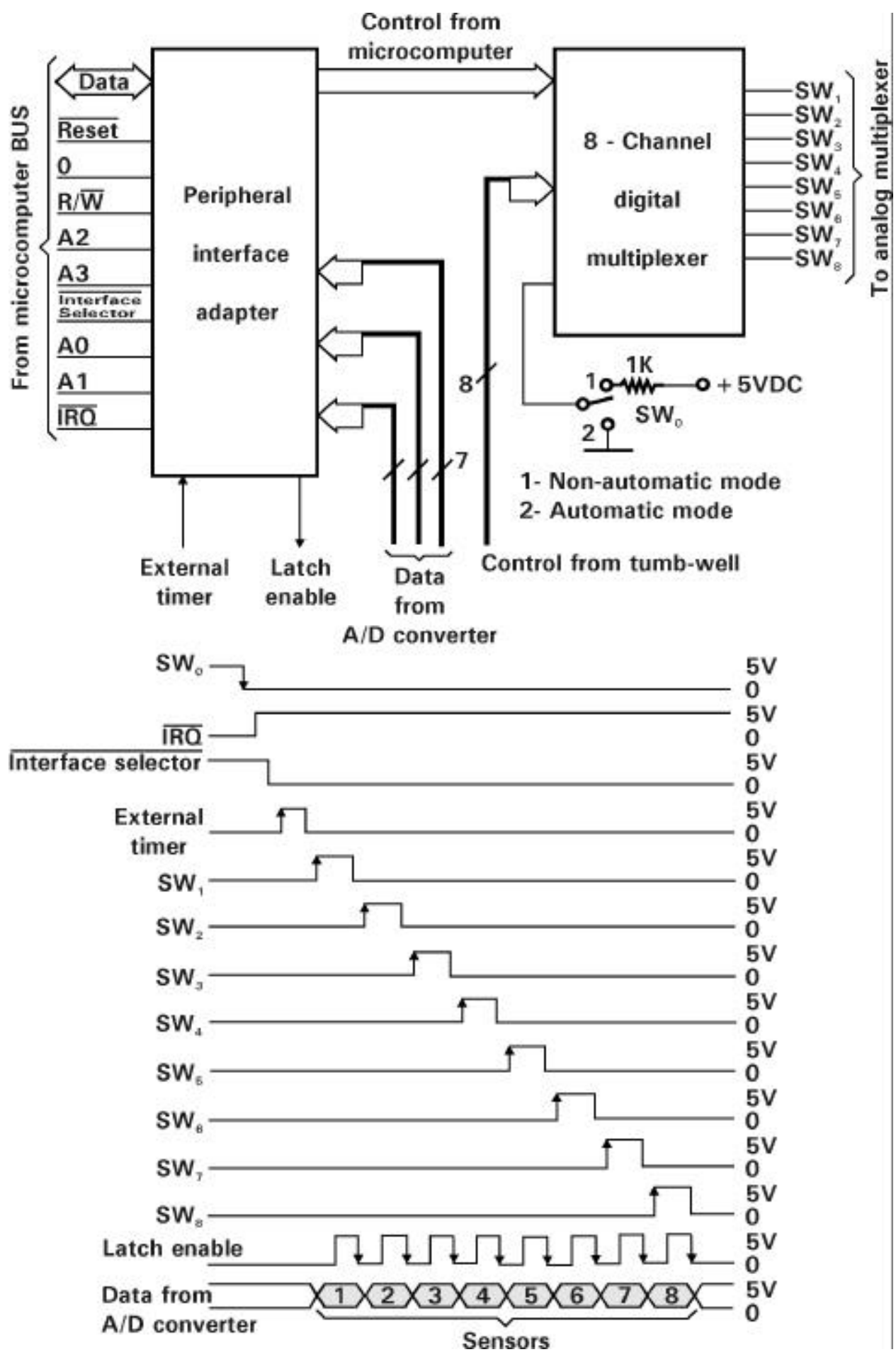

FIG. 2. Schematic diagram of interface with time sequence and mode selector operation. 
(a)

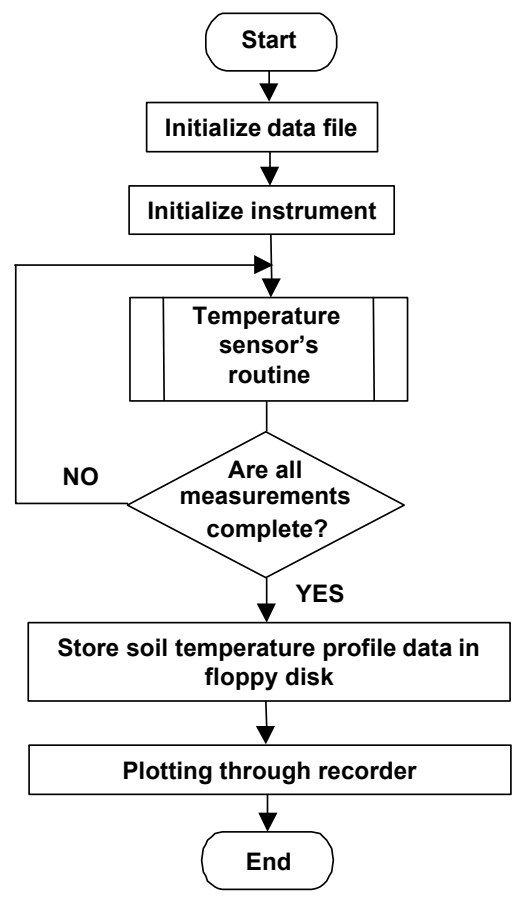

(b)

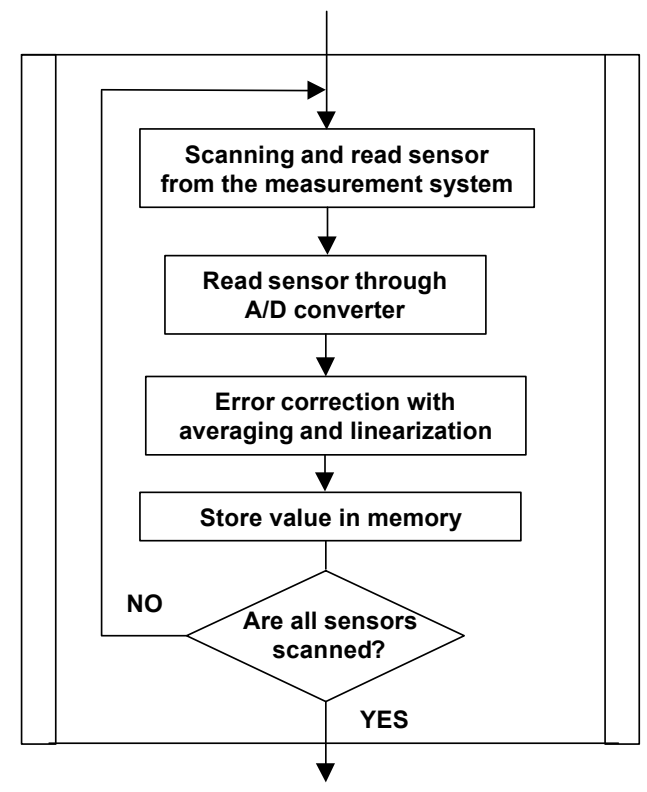

FIG. 3. (a) The algorithm used in automatic operation mode outlined in flowchart form; (b) temperature sensor's routine outlined in block diagram form.

\section{RESULTS AND DISCUSSION}

Under field conditions, offset was less than $2 \mu \mathrm{V}$. Therefore, the instrument operated under field conditions, i.e., withstood environmental interference like electromagnetic induction generated by lightning and relative humidity effects on the electronic circuit board. A study of the instrument's dynamic performance showed settling time amounted to $18 \mu \mathrm{s}$, almost independently of the temperature range.

Figs. 5 and 6 show part of temperature variation data for a 3-day period for both grass-covered and bare soil. Soil temperature data taken during a 60 -day period formed this dataset. It contained information from eight sites, i.e., at depths of 2, 4, 6, 8, $16,32,64$ and $128 \mathrm{~cm}$, (approximately $94.5 \mathrm{~W}$ longitude and $34.0 \mathrm{~N}$ latitude). These observations are primarily taken individually from sensors. The data were checked for internal consistency, compared to climatological limits, checked serially, and evaluated against surrounding stand-alone thermometers. Quality control flags were appended to each sensor to show how it fared during the editing to indicate what, if any, action was taken. The data, therefore, consist of observed values. Interpretation of the soil temperature data was based on graphs of temperature data and variation at 2 to $128 \mathrm{~cm}$ depths during three days. These data show a soil temperature increase at the lesser depths during morning hours. Amplitude de-

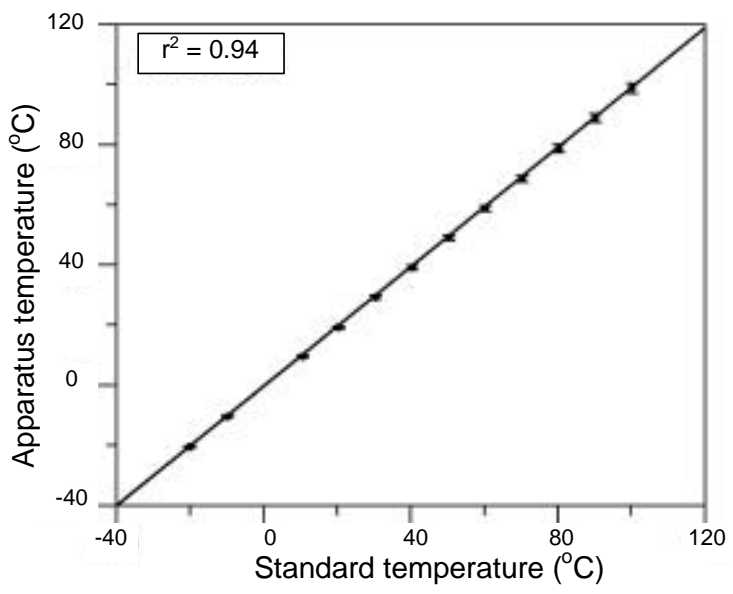

FIG. 4. Typical calibration curve for one sensor. 
creased with depth and, markedly in grass-covered soil, corroborating data presented in the literature. Results also confirmed the value of features allowing soil temperature acquisition at eight depths for investigating a wide soil profile; minimization of soil disturbance effects during sensor installation; operation range within temperature of at least $-10.0^{\circ} \mathrm{C}$ up

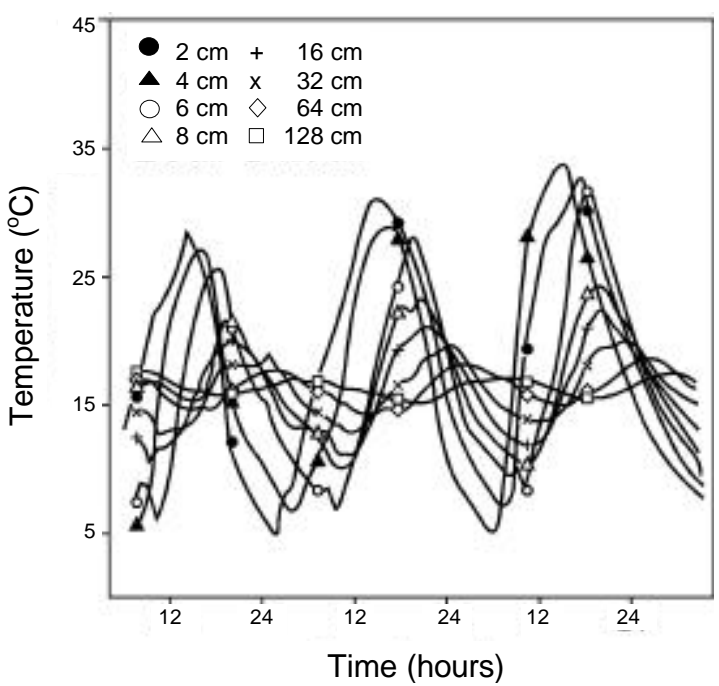

FIG. 5. Soil temperature variations at 2 to $128 \mathrm{~cm}$ depth during three days (with grass soil).

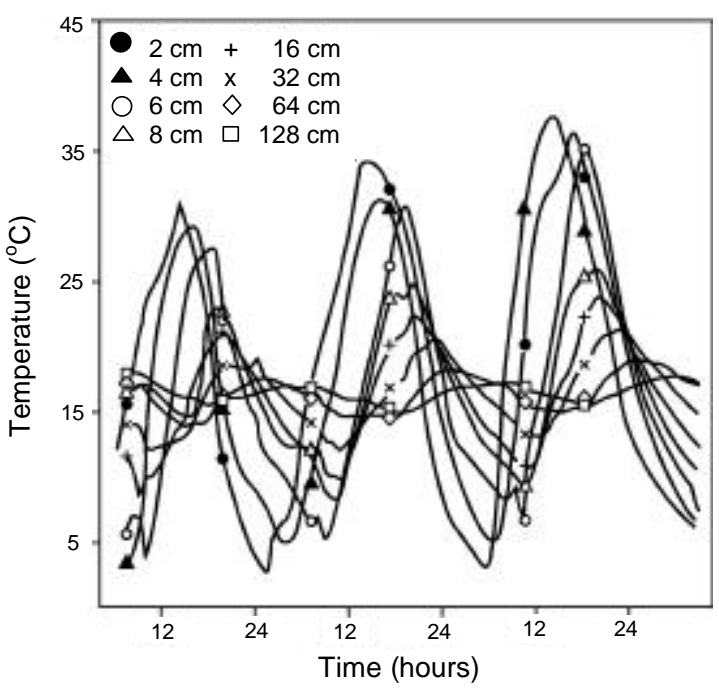

FIG. 6. Soil temperature variations at 2 to $128 \mathrm{~cm}$ depth during three days (with bare soil). to $50.0^{\circ} \mathrm{C}$, that of soil temperature at several depths year-round; and resolution (i.e., $1.0^{\circ} \mathrm{C}$ ) making possible detection of temperature variation at a depth $128 \mathrm{~cm}$, where amplitude versus time is smallest. Besides, the instrument's ability to make automatically many measurements for a soil profile ranging from 2 to $128 \mathrm{~cm}$ depth without moving the sensors allows evaluation of both spatial and temporal temperature pattern variability.

\section{CONCLUSIONS}

1. A compact, simple, reliable low-cost, highly accurate instrument for in situ soil profile temperature measurements, with potential application in the soil science area is described.

2. A simulation improves the temperature detection signal/noise ratio, making possible optimal sensitivity selection.

3. By using small inner fast-response volume sensors, the instrument minimizes soil disturbance effects during sensor installation, accelerating use of automation in soil data monitoring and respecting consumer demand for environmentally friendly devices.

\section{ACKNOWLEDGEMENTS}

To CNPq, Embrapa-Centro Nacional de Pesquisa e Desenvolvimento de Instrumentação Agropecuária, and University of California, LAWR Department, Davis, for financial and institutional support; to Mr. Monzane and Mr. Souza, for the drawing work.

\section{REFERENCES}

ALLMARAS, R.R.; BURROWS, W.C.; LARSON, W.E. Early growth of corn as affected by soil temperature. Soil Science Society of America. Proceedings, Madison, v.28, p.271-274, 1964.

BLACKMORE, S. Developing the principles of precision farming. In: INTERNATIONAL CONFERENCE ON AGROPOLES AND AGRO-INDUSTRIAL TECHNOLOGICAL PARKS-AGROTECH' 99, 1999, Barretos. Proceedings. Barretos : Associação Nacional de Entidades Promotoras de Empreendi- 
mentos de Tecnologias Avançadas/Instituto Barretos de Tecnologia, 1999. p.75-77.

COFFMAN, F.A. The minimum temperature of germination of seeds. American Society of Agronomy. Journal, Madison, v.15, p.257-270, 1923.

DUBETZ, S.; RUSSELL, G.C.; ANDERSON, D.T. Effect of soil temperature on seedling emergence. Canadian Journal of Plant Science, Ottawa, v.42, p.481-487, 1962.

EMBRAPA (Brasília, DF), Paulo Estevão Cruvinel. Medidor digital multissensor de temperatura para solos. BR n. PI 8903105-9. 26 jun. 1989. Revista de Propriedade Industrial, Rio de Janeiro, n.983, p.51, ago. 1989.

GIST, G.R.; MOTT, G.O. Some effects of light intensity, temperature and soil moisture on the growth of alfalfa, red clover and birdsfoot trefoil seedlings. Agronomy Journal, Madison, v.49, p.33-36, 1957.

GUPTA A.; TOONG, H.D. Microprocessors: the first twelve years. Proceeding of the IEEE, New York, v.11, n.71, p.1236-1256, 1983.

HASFURTHER, V.R.; BURMAN, R.D. Soil temperature modeling using air temperature as a driving mechanism. Transactions of the ASAE, St. Joseph, v.17, p.78-81, 1979.
NERPIN, S.V.; CHUDNOVSKII, A.F. Physics of the soil: Israel program for scientific translations. Jerusalem : Keter, 1970. 466p.

ROSENA, A. A mathematical model for simulation of the thermal behavior of bare soils based on heat and moisture transfer. Delft : Netherlands Center for Remote Sensing, 1975. 88p. (Publication, 11).

SCHIELDGE, J.P.; KAHLE, A.B.; ALLEY, R.E. A numerical simulation of soil temperature and moisture variations for a bare field. Soil Science, Baltimore, v.133, p.197-207, 1982.

SMITH, O. Production storing processing. Westport : Avi, 1968. 232p.

VIEIRA, S.R.; HOFFIELD, J.L.; NIELSEN, D.R.; BIGGAR, J.W. Geostatistical theory and application to variability of some agronomical properties. Hilgardia, Berkeley, v.51, n.3, p.75-82, 1983.

WIERENGA, P.J.; NIELSEN, D.R.; HORTON, R.; KIES, B. Tillage effects on soil temperature and thermal conductivity. In: SOIL SCIENCE SOCIETY OF AMERICA ANNUAL MEETING, 1980, Detroit. Proceedings. Madison : Soil Science Society of America, 1982. p.69-90.

WIJK, W.R. van. Physics of plant environment. Amsterdam : North-Holland, 1963. 382p. 